International Journal of Instruction e-ISSN: 1308-1470 • www.e-iji.net

Article submission code: 20190821181041

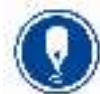

January $2021 \bullet$ Vol.14, No.1

p-ISSN: 1694-609X

pp. 411-426

Received: 21/08/2019

Revision: 28/06/2020
Accepted: 20/07/2020

OnlineFirst:24/10/2020

\title{
Self-Assessment Based Counseling: A Further Study Planning Service in High School
}

\section{Syarifuddin Dahlan}

Dr., Department Guidance and Counseling, Universitas Lampung, Indonesia, syarif.dahlan@yahoo.co.id

This study aims to test the effectiveness of Self-Assessment Based Counseling services using Quasi-Experimental Pretest-Posttest Nonequivalent Group Designs. Research subjects totaled 105 high-school students consisting of 53 male students and 52 female students. Subjects were divided into two groups, 55 students in the experimental group, and 50 students in the control group. The research data on the form of a certainty score of students' further study plan was measured using the Certainty Scale of Further Study Plan. The results indicate that self-assessment counseling services are effective to help high school students improve their further study plan certainty. The average score of students from the experimental group increased significantly compared to students from the control group. The scores of male and female students did not differ significantly, and their mean scores showed equal improvement. The use of self-assessment in further study counseling does not depend on the sex of the students, both for men and women equally effectively.

Keywords: counseling, self-assessment, further study planning, students, high school

\section{INTRODUCTION}

Planning further study is part of career planning. The result of this activity is the right decision on the study plan that students will make after completing the study (Babarovič, Devič, \& Blažev, 2019). For example, further study for students undergoing primary education is secondary education, while for those undergoing, high school is a college or university.

The decision on a student's further study plan is not a gift from others, nor an accidental occurrence. Instead, it should be planned and created by the student through experience, which continues throughout his or her life (Choi, Kim, \& Kim, 2015; Greenwood, 2008). In other words, one's success in creating a proper further study plan is, in fact, the result of his or her career maturity (Alvarez-Gonzalez, 2008; Borges, Richard, \& Duffy, 2007). Therefore, guidance to high-school students in creating their comprehensive further study plan is always emphasized and becomes a priority of career counseling services in schools.

Citation: Dahlan, S. (2021). Self-Assessment Based Counseling: A Further Study Planning Service in High School. International Journal of Instruction, 14(1), 411-426. https://doi.org/10.29333/iji.2021.14124a 
In the school setting, the help of advanced study planning with the students is part of the educational effort. This assistance service is run, either by the school counselor (YukselSahin, 2012) or guidance teacher (Sevinc, Tasci, \& Demir, 2012) professionally. Counseling, after all, is a complex process that encompasses various interventions with special expertise. The success of counseling is achieved through (1) The active and full involvement of responsibility between counselor and counselee, (2) the experiences of counselors born of their professional identity (Tapson, 2016), and, (3) the emotional experiences, meaning of life, and the distress attached to their economic status (Pezirkianidis, Stalikas, Efstathiou, \& Karakasidou, 2016) are examples of important variables that can color the quality of service counseling from a counselor. For counseling in schools to be effective, there needs to be a service model capable of integrating the collaborative, dialectical, and systemic aspects of the counseling process with teachers (Kourkoutas \& Giovazolias, 2015).

So far, in our schools, there is no empirical evidence suggesting the use of a particular model and/or way of counseling which is more effective than others. Along with the pattern of such planning counseling, the result was not optimal (Makela \& Hoff, 2019). Students in high school are generally unable to state the study plan they will undertake after graduation (Liu, Hao, \& Li, 2006). Most of them seem hesitant, and some cannot make any decision about the career plan, including their study plan (Burrow-Sanchez \& Lopez, 2009). Also, for some others, their further study choice was chosen by others. In other words, they chose but did not decide which study plan to undertake (Obi, 2015). Students' study plan decisions are often made not based on careful consideration of adequate self-information such as their strengths and weaknesses, their compatibility with their talents, interests, and skills (Naylor \& Krumboltz, 1994), but rather on their study plan choices, generally made based on the wishes of family members, peers, or other people.

Interdependent family-centric career (Pekerti, 2008) is still influencing high school students' study plans. A student who is hesitant and cannot plan his studies further can be caused by various factors such as, (1) the student has a lot of potentials and many choices but he or she cannot decide one as his or her goal, or (2) the student does not get adequate self-information support (Lease, 2006).

The activity of matching the self-factors with a particular type of expertise from a particular study group becomes an important stage in the decision-making process of further study plan choice (Perdue, Reardon, Peterson, 2007). Match between these two factors. believed to be able to determine one's success in completing his studies (Aljojo, 2016). The more fitness between the student and the demands of the learning tasks in his or her study, the more possibility to the success of his or her study (Durr \&tracy, 2009; Gottfredson \& Duffy, 2009). Conversely, failure will always lurk when the gap between the demands of learning activities and a student is wide enough. In summary, self-factors such as beliefs, aptitudes, interests, abilities (Naylor \& Krumboltz, 1994), attitudes, and traits and values that exist in a person should be an important consideration in further study planning in addition to the demands of the expertise of a study group (Harris, Winkowski, \& Engdahl, 2007). 
Therefore, information about oneself and the types of expertise of a study group offered by an educational institution are two important factors in further study planning. Consideration of the fitness between the self-aspects and the further study plan choice (Kemboi, Kindiki, \& Misigo, 2016), becomes an important part for the accuracy of a career decision making (Holland, 1997). Career guidance and counseling experts have long recognized and always include these considerations in every career planning service, including further study plans (Balgama and Uzunboylu, 2017; Perdue, et al, 2007). Therefore, a person who is planning further study is required to first explore his or her vocational personality and environment (Gootfredson \& Duffy, 2008) to obtain an adequate understanding, both on self-aspects and the types of expertise of a study group addressed. Although this does not guarantee to be able to produce a good further study plan, but a preliminary step like this is a valuable start for the person in planning further study options. Moreover, making a well-defined further study plan is better than making a study plan that is not yet clear for one-self.

This study offers an alternative service for an effective way to help high school students plan their further study appropriately. This counseling service is conducted using selfassessment in the form of the Self-Vocational Preference Inventory (S-VPI; Dahlan, 2010). This inventory serves as an instrument as well as a service intervention. The inventory contains statements that allow students to do self-assessment and at the same time to recognize some occupations or positions that characterize particular expertise. Self-assessment based counseling has become an interesting discussion among career counselors (Patton \& Mclleveen, 2009). The discussion is more interesting when counselors are confronted with the traits of the 21st-century teenagers (Burnham, 2009) and "Motherhood in 21st Century" (Medina \& Magnuson, 2009) as well as the direction of a more complex exploration of career outlook (Zikic \& Hall, 2009). In other words, further study planning services at schools were provided according to the characteristics and creativity of the school counselors concerned (Burrow-Sanchez \& Lopez, 2009).

In summary, the advantage offered by this model counseling service, is that it allows students to assess their potential (Gottfedson \& Duffy, 2008). In this counseling, students are also allowed to administer, self-score, and interpret themselves (Gottfredson \& Johnstun, 2009; Holland, 1997). Along with the self-assessment activities, students are, indirectly, introduced to the various skills of some occupations in inventory. This kind of counseling process is believed to be able to lead the students to understand themselves and recognize the types of expertise in a study group so that the discovery of further study options is more easily achieved.

In general, this study aims to answer the question: Is self-assessment-based counseling effective to help high school students plan their further study? Specifically, this study would like to answer the following questions:

1. Does the certainty score of students' further study plan increase significantly after going through self-assessment based counseling?

2. Is there a significant difference between the certainty score of students' further study plan in the experimental group and the control group? 
3. Is there a significant difference in the certainty score of students' further study plan for male and female students?

\section{METHOD}

\section{Design}

This study aims to examine the effectiveness of a self-assessment based counseling service for further study planning through quasi-experimental research with Pre-testpost-test Nonequivalent Group Design (Heppner, Wampold, \& Kivinghan, 2008). This design allows all research participants, both in the experimental group and in the control group, to get the same pre-test and post-test on the degree of certainty of further study plan option. The sampling technique uses non-random sampling.

\section{Participants}

This study was conducted at high school in Bandar Lampung City, involving 105 students in four classes. The experimental group $=55$ students ( 26 male and 29 female), the control group $=50$ students $(27$ male and 23 female). Before the treatment was initiated, all participants received a pre-test of the certainty of a further study plan. After that, each participant receives further study planning services. Participants in the experimental group received services using self-assessment counseling, while the participants in the control group received placebo services --- "left alone".

\section{Instruments}

Data on the certainty of the students' further study plan were collected using a Study Plan Certainty Scale (SPCS). This scale consists of two parts, a statement about the name of the study/type of expertise planned by the student for their further study and the assessment of the certainty scale.

The scoring criteria of students' SPCS and the criteria for further study plan certainty are set out as shown in Table 1 below.

Table 1

The statement, Score, and Answer Category List

\begin{tabular}{|c|c|c|c|}
\hline No. & Statements of Further Study Plan Certainty & Score & Category \\
\hline 1. & $\begin{array}{l}\text { I will follow the study plan that I have set and will pursue it } \\
\text { throughout my life. }\end{array}$ & 6 & \multirow[t]{2}{*}{ Firm } \\
\hline 2. & I am not planning to change my existing study plan. & 5 & \\
\hline 3. & I am somewhat doubtful about my study plan. & 4 & \multirow[b]{2}{*}{ Doubtful } \\
\hline 4. & I sometimes wonder if the study plan I have chosen is correct. & 3 & \\
\hline 5. & I still have a lot of doubts about the study plan have chosen. & 2 & \multirow[b]{2}{*}{ Not Firm } \\
\hline 6. & $\begin{array}{l}\text { I have one study plan, but I often ask if the study plan is a good } \\
\text { one. }\end{array}$ & 1 & \\
\hline
\end{tabular}

SPCS has been validated with an approval index of 0.84 points from three raters. The stability index of 0.885 points is categorized as high (Aiken, 1988). Thus the scale is quite valid and reliable to measure the certainty of the student's study plan. 


\section{Procedure}

To facilitate the treatments, the main researcher appointed two Assistant counselors (one was from the school counseling teacher - participants' classroom counselor, and another one was assistant lecturer in career guidance and counseling course at Lampung University). Assistant counselors are those who asked to participate in providing counseling services. The details of each assistant counselor task were outlined by the main researcher in accordance to the research purposes and the basic principles of counseling services at the school.

In the counseling process, participants in the experimental group were divided into five counseling groups, each consisting of 11 students. All participants in each of these counseling groups received a counseling phase following the Self-Directed Counseling stages (Dahlan, 2017). In such a counseling process there are four stages which include: Summary Code Discovery Stage by the student through his or her assessment, Summary Code Interpretation Stage, Further Study Planning Stage, and Follow-up Stage. The whole series of counseling processes are carried out in three to four meetings; one to two meetings are conducted in the classroom and two to three meetings are conducted in the counseling group. Classroom meetings are held to complete students' Code Summary Discovery Stage activity, whereas group counseling meetings are held to complete the activities of the next stages. Ideally, the total time required for each student to complete this counseling ranges from 180-210 minutes.

\section{Analyses}

The data on the students' further study plan certainty were analyzed through descriptivequantitative approaches using statistical techniques, in particular, to test the difference of mean score between groups. All calculations for this data analysis have been performed using Statistical Product and Service Solutions (SPSS).

\section{FINDINGS}

Description of pre-test and post-test data of further study plan certainty from male and female students, the experimental group and the control group can be seen in Figure 1.

The plot box indicates that the mean score pre-test of further study plan certainty of each group is almost similar (the experimental group: male $=3.46$ and female $=3.69$; the control group: male $=3.48$ and female $=3.57$ ) with the relatively similar distribution. The post-test data shows that almost all student's scores are increasing and are far above the pre-test data, except for some male students from the control group - slightly decreased (the experimental group: male $=4.46$ and female $=4.69$; the control group: male $=3.48$ and female $=3.83$ ). In other words, there is a difference in the mean score in the pre-test and post-test data of each group.

The model test has been done by examining the difference in mean score between groups based on the data in Figure 1 above. A summary of the results is presented in Table2. The paired Pre-test vs. Post-test data was examined using the Paired Sample Test, while the Control Group vs. the Experimental Group and male vs. female data pair were analyzed using ANOVA as presented in Table 3. 


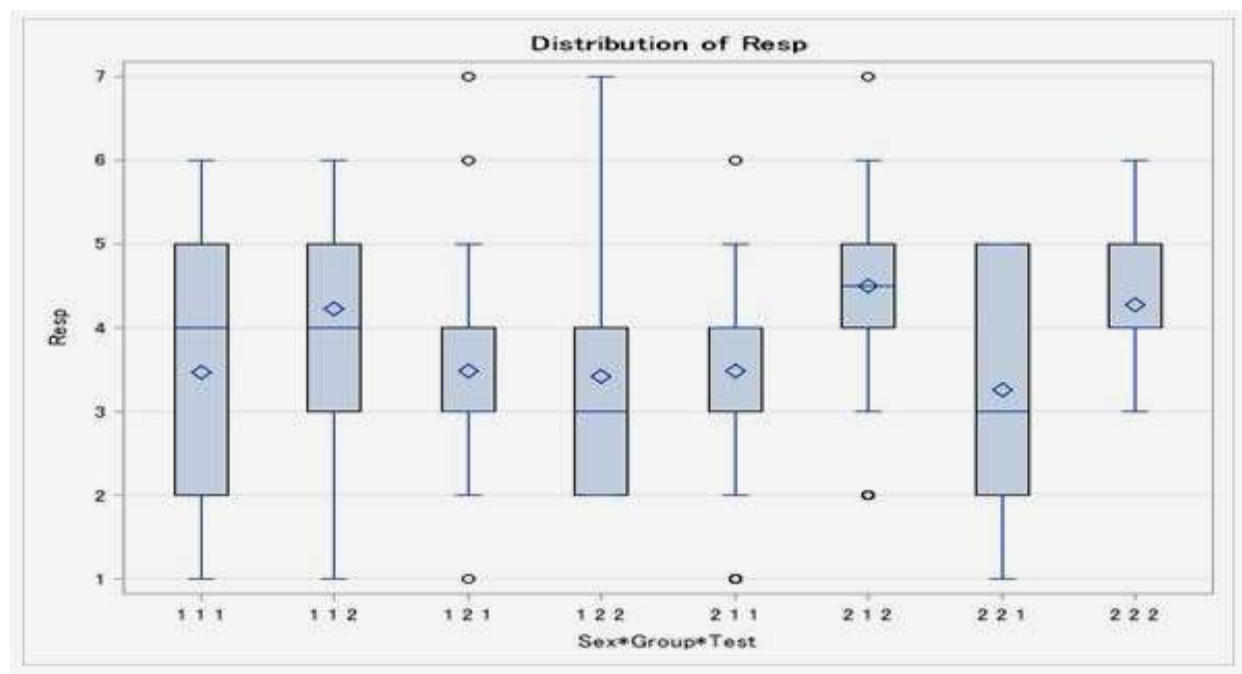

Figure 1

Distribution of box plots on subjects and gender grouping

Table 2

Summary of Analysis of Variance for Testing the Counseling Model

\begin{tabular}{lrlccl}
\hline Source & DF & Sum of Squares & Mean Square & F-value & Pr $>$ F \\
Model & 4 & $169.789 \mathrm{a}$ & 42.447 & 44.344 & 0.000 \\
Error & 100 & 44.344 & 0.443 & & \\
Corrected Total & 104 & 214.133 & & & \\
\hline
\end{tabular}

R-Squared $=.793$ (Adjusted R-Squared $=.785$ )

Table 3

Analysis of variance of mean score post-test of further study plan certainty between groups and genders of high school students

\begin{tabular}{lrllll}
\hline Source & DF & Type I SS & Mean Square & F- Value & p-Value \\
Group & 1 & 20.678 & 20.678 & 46.632 & 0,000 \\
Sex & 1 & .564 & .564 & 1.272 & 0,262 \\
Group*Sex & 1 & .375 & .375 & .846 & 0.360 \\
\hline
\end{tabular}

The result from the data analysis indicates a value of $\mathrm{F}=44,344$ ( $\mathrm{p}$-value $<0.000$ ). Thus, the counseling service model implemented in this study is effective to help students decide their further study plan.

\section{Results of Pre-test Vs Post-test Data Analysis}

The result of pre-test and post-test data analysis obtained t-test value $=7.297$ (p-value < $0.000)$ at a very significant level. This means that there is a very significant difference between the mean score of students' further study plan certainty before and after the treatment. The students' mean score after receiving self-assessment based further study planning counseling was higher (4.13) than the previous mean score (3.55). In other 
words, self-assessment based further study planning counseling improved the mean score of student's further study plan certainty significantly.

\section{Results of the Experimental Group and the Control Group Data Analysis}

The data analysis results of students' further study plan certainty score from the experimental group and the control group obtained $\mathrm{F}$ value $=46.632$ (p-value $<0.01)$ very significantly (See Table 3 ). This means that the mean score of certainty of further study plan between the experimental group (self-assessment-based counseling users) and the control group (users of other counseling services) differ significantly. The mean score of students' further study plan certainty who received self-assessment-based counseling was much higher (4.58) than the mean score of the control group (3.64). So that self-assessment-based counseling services have a better effect in helping students plan further studies in secondary school.

The mean score of male and female students who received self-assessment-based counseling services moved equally toward the expected increase (See Figure 2). Although female students look somewhat higher than male students there is no interaction between the sexes and student service groups (See Table 3).

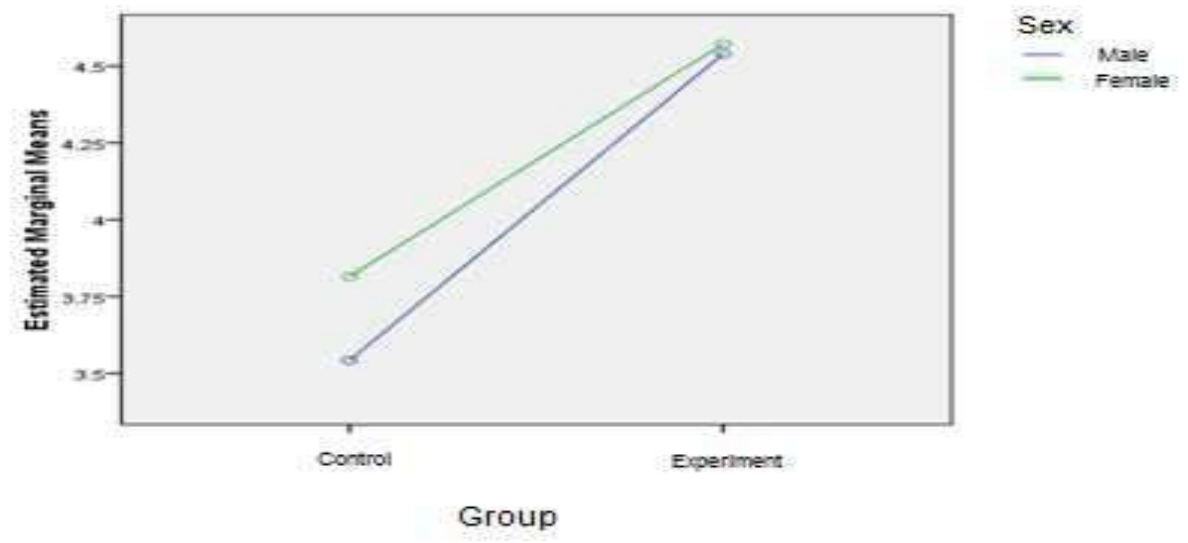

Figure 2

Estimated marginal means of post-test data in interaction analysis group * sex of high school students

\section{Results of Male and Female Data Analysis}

The mean score of male and female data analysis obtained $\mathrm{F}=1.272$ ( $\mathrm{p}$-value $=0.262$ ). This means that there are no significant differences in further study plans for male and female students. The mean score of their further study plan is likely to have a similar tendency. In other words, both the mean score of male and female students is equally increased after receiving counseling services. Although the mean score of female students (4.69) was higher than male students (4.46), the difference was not significant (See Table 3). 
The interaction plot of the mean score of male and female students in the experimental and control groups was different. The interaction plot of the mean score for male students can be seen in Figure 3, while for female students shown in Figure 4.

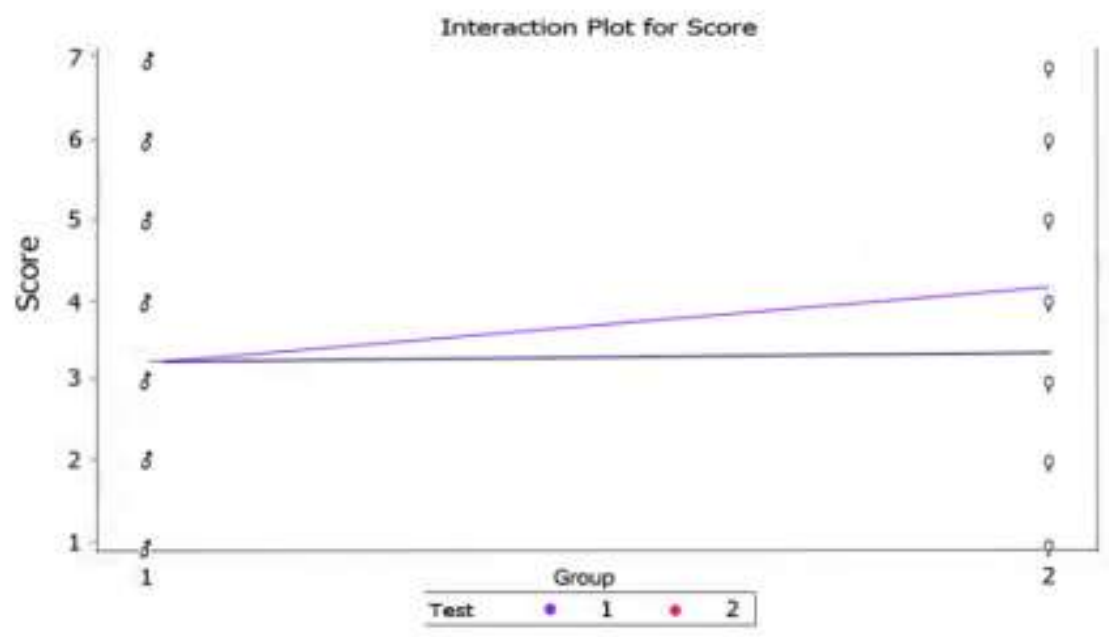

Figure 3

The interaction plot of the mean score of male students in group and test

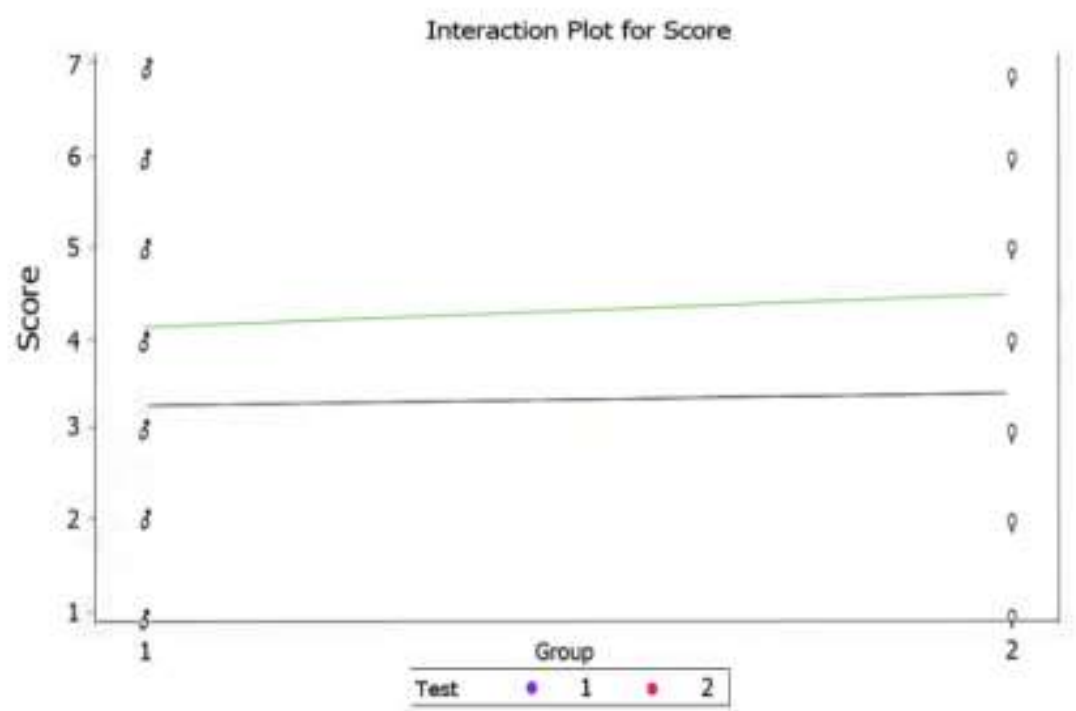

Figure 4

The interaction plot of the mean score of female students in group and test 


\section{DISCUSSION}

The empirical evidence found in this study indicates that the mean score of students' further study plan certainty increased significantly after they received self-assessmentbased counseling. The main score of students' further study plan certainty was 3.58 points, then after receiving the counseling service increased to 4.58 points. Although this assistance has not been able to deliver students to the optimal category of certainty, the increase in scores is significant.

Significant improvement in the mean score of certainty of further study choice plans in the experimental group students occurred probably due to the inherent superiority in this offered counseling. It is known that self-assessment-based counseling is characterized using the Self-Vocational Preferential Inventory (IPD-V; Dahlan, 2010) as the basis for both service and intervention. This inventory was specifically designed as a career counseling tool that contains some self-statements about a counselee's vocational personality classified into Holland's Typologies (1997). The directions outlined in undergoing self-assessment in this inventory allow the counselee to adequately explore careers through self-assessment, self-administered, self-scored, and self-interpreted activities. In other words, the self-assessment of counseling is undertaken by the counselee through his direction, ranging from assessment of activity preferences, position preferences, academic achievement, and self-estimation to the discovery of his summary code (SC). On the SC, a pattern that illustrates the similarity of the counselee's personality with the six personality types (Realistic, Investigative, Artistic, Social, Enterprising and Conventional).

Furthermore, the counselee immediately enters the counseling meeting in the context of the SC meaning that has been obtained from the results of his assessment. Based on the results of self-assessment, the counselee and counselor undergo counseling (individually or in groups) to explore the meaning of SC and find alternative career choices (majoring in further study and/or occupational fields) that are appropriate to him, so that the decision making for further study plans for students can be determined surely.

This study has supported the findings of previous studies, which reported that counseling interventions generally use the Holland model device is effective in career counseling interventions (Nauta, 2010;). For example, in helping students make certainty about their career choices (Dahlan, 2017;) and choose a career that matches their personality (Aljojo, 2016). Those supportive cross-study findings are generally related to the use of theory (Yilmaz, 2017; Bullock, Andrews, Braud, \& Reardon. (2009); Gottfredson \& Johnstun, 2009), assessment techniques (Meireles \& Primi, 2015), and classification systems (Morgan \& Bruin, 2018; Holland, 1997). However, this study has proven that self-assessment-based counseling can help counselees understand themselves (vocational personality) and their environment (the world of work and/or study majors) needed in making his career decision, in particular, making a certainty of further study plans. 
Organizing such inventive content and referrals has made counseling services a relatively simple activity in helping students understand themselves and their environment. In brief, self-assessment activities in counseling are done by students to determine their personality resemblance to six types of vocational personality (RIASEC). The service encourages the counselees to declare their occupational dreams and provides psychological meaning to their further study plan firmly. The result of the self-assessment will be the basis for the next phase of the counseling activity to the study up to the decision making of the certainty of the advanced study plan that is desired.

Data from student self-assessment results can also be used by counselors to organize the data they get, either from interviews, recordings, interest and talent instruments. In summary, in this self-assessment based counseling, both counselee and counselor can use theoretical concepts inherent in such data. Their communication may improve, and the counselor's influence may also increase. These advantages can differentiate the ability of the counselee to understand and use some other therapeutic classification system. Such conditions are thought to have created an atmosphere of pleasant counseling so that freedom of counselee and counselor to do more suitable and complete activities in finding their choice of the study plan appropriately and firmly.

In summary, through this series of counseling activities, it is believed that optimal assistance is given to the counselee in exploring his career. In other words, the characteristic inherent in self-assessment-based counseling is the superiority of the services offered, and this is believed to have made effective counseling so that the difference in the average score of certainty in the choice of further study plans between students in the experimental group, and the control group occurs very significantly.

The study also found that there was no interaction between gender and the way of interaction in counseling so that an increase in the average score of certainty in further study plans for male and female students did not differ significantly. This finding is in line with the results of Fort \& Murariu's (2018) research, which confirms that gender and educational barriers, social support and career barrier-coping efficacy, educational barriers and indecision, career barrier-coping efficacy and indecision, career barriers and indecision, social support and indecision were all not significantly correlated. In contrast, the findings of the present study differ from the research results of Watts, Frame, Moffett, Van Hein, \& Hein (2015) which reports that college-age women aspired to attain slightly more prestigious careers than their male peers. There is no difference in the average score of certainty of further study plans shown by male and female students in this study may also be caused by the application of counseling that does not require students to gender differences in achieving counseling goals. However, these findings are interesting to study further to get a clearer understanding of the relationship between gender and career.

In the school setting, further study planning assistance to the students is part of the educational effort. As part of education efforts, indeed, counseling is a learning process, especially for the counselees themselves. The learning process for the counselee happens when there is a close dialogue with the counselor to direct him or her to achieve 
the desired counseling goals. A wise decision for the counselee will be obtained following the degree of his or her career maturity along with the counselor's direction in the counseling process. Although there is a disparity between research intervention and counseling practice (Duarte, 2017), it is believed that learning experiences such as selfconstruction, and career (Cook \& Maree, 2016) in the counseling process have helped participants determine the direction of further studies. In other words, further study planning is an educational effort aimed at producing a wise decision determined by the ability of the counselee to match him/herself with the chosen study plan appropriately and firmly.

Self-assessment based counseling for further study planning is an alternative service offered to high school counselors. For a society that views the provision of tools and conducts psychological testing as an "expensive" or "rare" thing. Perhaps this way of counseling services can be a useful alternative. Based on research findings, selfassessment counseling has several advantages. In terms of effectiveness, students who undergo counseling in this way turned out to have been able to plan his career (further study) following their potential. In terms of efficiency of time, effort, and cost of the service offered this is considered quite efficient. The whole series of counseling activities takes about 120-150 minutes. Such periods appear to be shorter when compared to the time required for counseling by taking psychological testing, such as talent test and personality inventory, individually, likewise with energy and cost. Such counseling arrangements are sufficiently carried out by a trained counselor with the necessary self-assessment tool. Counseling using IPD-V as a self-assessment tool has enabled students to self-penalize, self-administer, and self-interpretation. Furthermore, self-assessment counseling is compatible with the population and is also suitable for a variety of service strategies, both individually and in groups.

So far, the main consideration in further study planning, especially in our schools in the country, is the score of subject groups (Natural Science, Social Science, Language, and/or Religion). Testing and/or psychological assessment to detect students' selfpotential are rarely done. It is still a special activity and rare, even if it is conducted. The results of testing and/or assessment activities are often used as display data neatly stored in the school drawer. Decisions on study plans, such as the choice of study majors, are generally taken by the school (homeroom teacher and/or counseling teachers). Students know and accept the study choice decision through the school announcement or the Rapport Book. In other words, the selection of a study plan, or group of study majors for high school students has been determined, or "elected" by others, rather than through careful planning and deliberation. As a result, often we find students who are unable to demonstrate optimal learning achievement, change their major while undertaking a study program, and most disappointingly, students fail in their studies.

A series of self-assessment based counseling activities is organized as follows (Dahlan, 2017): First Phase, finds Summary Code (SC) of the counselee through assessment of activity preference, job preference, academic achievement, and self-estimation. Second Phase, SC interpretation, and discovery of alternative further study plan choices. Third Phase, the decision of the most appropriate further study plan choice. Advanced 
Phase, make a deeper introduction and preparation for a planned course or program of study. Through such activities, it is hoped that the students can find appropriate jobs related to their personality patterns so that it will be relatively easy to decide an alternative further study plan appropriately.

This self-assessment based counseling is conducted with special guidance. The guidance contains an explanation of (1) the characteristics of self-assessment based further study planning counseling, and (2) a series of activities that the counselor must accomplish in achieving the counseling service objectives, ranging from prior counseling to postcounseling follow-up activities. By following the guidance, it will be easier for the counselor to direct the counseling activities that must be followed by students to find the desired further study plan more quickly.

\section{CONCLUSIONS}

Self-assessment-based counseling is effective in helping high-school students to set up a further study plan appropriately. The mean score of the students' further study plan certainty after using the assessment based further study planning counseling improved significantly, which is much higher than the mean score of the control group students. The use of this model service turned out does not depend on the student's gender; both male and female students of this counseling service showed equal mean score improvement and did not significantly differ.

Based on these findings, it is recommended that counselors consider the use of assessment-based counseling as an alternative service in helping high-school students make decisions on their study plans, both to choose groups of subjects in high school and study programs in higher education later. In the future, a similar follow-up study may be carried out on an extended subject, for example, to junior high school students to help them make high school study plan decisions.

\section{REFERENCES}

Aiken, L.R. (1997). Psychological Testing and Assessment, 9th ed. Needham Heights, MA, US: Allyn \& Bacon.

Aljojo, N. (2016). Choosing a Career Based Personality Matching: A Case Study of King Abdulaziz University. International Journal of Advanced Computer Science and Applications, 7(2), 215-221.

Alvarez-Gonzalez, M. (2008). Career maturity: a priority for secondary education. Electronic Journal of Research in Educational Psychology, No 16, 6(3), 749-772.

Balgama, B., \& Uzunboylu, H. (2017). The relationship between career decisionmaking self-efficacy and vocational outcome expectations of preservice special education teacher.South African Journal of Education, 37(4): Art.\# 1520, 11 pages. https://doi.org/10.15700/saje.v37n4a1520. 
Babarović, T., Dević, I., \& Blažev, M. (2019). The effects of middle-school career intervention on students' career readiness. International Journal for Educational and Vocational Guidance.19 (1), 19-39.

Borges, N.J., Richard, G.V., \& Duffy, R.D. (2007). "Career maturity of students in accelerated versus traditional programs". The Career Development Quarterly, 56(2), $171-176$.

Bullock, E. E., Andrews, L., Braud, J., \& Reardon, R. C. (2009). Holland's theory in an international context: Applicability of RIASEC structure and assessments. Career Planning and Adult Development Journal, 25(4), 29-58.

Burnham, J. J. (2009). Contemporary fears of children and adolescents: Coping and resiliency in the 21st century. Journal of Counseling \& Development. Winter 87(1), 2835 .

Burrow-Sanchez, J. J., \& Lopez, A. L. (2009). Identifying substance abuse issues in high schools: A national survey of high school counselors. Journal of Counseling \& Development, 87(1), 72-79.

Durr II, M. R., \& Tracey, T. J. (2009). Relation of person-environment fit to career certainty. Journal of Vocational Behavior, 75(2), 129-138. http://doi.org/10.1016/j.jvb.2009.05.003

Choi, Y., Kim, J., \& Kim, S. (2015). Career development and school success in adolescents: The role of career interventions. The Career Development Quarterly, 63(2), 171-186. http://doi.org/10.1002/cdq.12012

Cook, A., \& Maree, J. G. (2016). Efficacy of using career and self-construction to help learners manage career-related transitions. South African Journal of Education, 36(1), Art.\# 1225, 11 pages. https://doi.org/10.15700/saje.v37n4a1225

Dahlan, S. (2017). "Self-directed counseling: An Alternative service model of career choice certainty". Science International (Lahore) Journal. 29(5), 1011-1016.

Dahlan, S. (2010). Model Konseling untuk Merencanakan Pilihan Karier Konseli [Disertasi]. Sekolah Pascasarjana, Universitas Pendidikan Indonesia, Bandung.

Duarte, M.E. (2017). Career counseling research-practice disparities: What we know and what we need to know. South African Journal of Education, 37(4): Art.\# 1424, 13 pages. https://doi.org/10.15700/saje.v37n4a1424.

Fort, I., \& Murariu, A. (2018). The paths between gender, barriers, social support, coping efficacy and vocational indecision. International Journal for Educational and Vocational Guidance, 18(3), 241-256. https://doi.org/10.1007/s10775-018-9359-4 
Gottfredson, G.D., \& Johnstun, M.L. (2009). John Holland's contributions: A theoryridden approach to career assistance. The Career Development Quarterly, 58(2), 99107.

Greenwood, J.I. (2008). Validation of multivariate career and educational counseling intervention model using long-term follow-up. The Career Development Quarterly, 56(4), 353-361.

Harris, J.I., Winskowski, A.M., \& Engdahl, B.E., (2007). Types of workplace social support in the prediction of job satisfaction. The Career Development Quarterly, 56(2), 150-156.

Heppner, P.P., Wampold, B.E., \& Kivinghan, D.M. (2008). Research Design in Counseling. ( $3 r d E d$.). Thomson; Brooks/Cole.

Holland, J. L. (1997). Making vocational choices: A theory of vocational personalities and work environments (3rd ed.). Odessa, FL: Psychological Assessment Resources.

Kemboi, R. J. K., Kindiki, N., \& Misigo, B. (2016). Relationship between personality types and career choices of undergraduate students: A case of Moi University, Kenya. Journal of education and practice, 7(3), 102-112.

Kourkoutas, E., \& Giovazolias, T. (2015). School-Based Counselling Work with Teachers: An Integrative Model. The European Journal of Counselling Psychology, 3(2), 137-158, http://doi.org/10.5964/ejcop.v3i2.58

Lease, S.H. (2006). Factors predictive of the range of occupation considered by African American junior and senior in high school. Journal of Career Development;32,333-350.

Liu, C.J., Hao, F., \& Li, S. (2006). Career decision-making difficulties of college student and its relationship with self-efficacy. Chinese Journal of Clinical Psychology, $4,502-506$.

Makela, J. P., \& Hoff, K. (2019). Career Outcomes Data from Social Media: Examining Quality in Current Practices. The Career Development Quarterly, 67(3), 220-235. http://doi.org/10.1002/cdq.12192

Medina, S. \& Magnuson, S. (2009). Motherhood in 21st Century: Implications for counselor. Journal of Counseling \& Development, 87(2), 90-97.

Meireles, E., \& Primi, R. (2015). Validity and reliability evidence for assessing Holland's career types. Paidéia (Ribeirão Preto), 25(62), 307-315. https://doi.org/10.1590/1982-43272562201504.

Morgan, B., \& De Bruin, G. P. (2018). Structural validity of Holland's circumplex model of vocational personality types in Africa. Journal of Career Assessment, 26(2), 275-290. https://doi.org/10.1177/1069072717692747 
Nauta, M. M. (2010). The development, evolution, and status of Holland's theory of vocational personalities: Reflections and future directions for counseling psychology. Journal of counseling psychology, 57(1), 11. https://doi.org/10.1037/a0018213.

Naylor, F.D., \&Krumboltz, J.D. (1994). The independence of aptitudes, interests, and career beliefs. The Career Development Quarterly, 43(2), 152-160.

Obi, O. P. (2015). Constructionist career counseling of undergraduate students: An experimental evaluation. Journal of Vocational Behavior, 88, 215-219. http://doi.org/10.1016/j.jvb.201503.009

Patton, W., \& McIlveen, P. (2009). Practice and research in career counseling and development-2008. The Career Development Quarterly, 58(2), 118-161.

Pekerti, A. A. (2008). The interdependent family-centric career: Career perspective of the overseas Chinese in Indonesia. The Career Development Quarterly, 56(4), 362-337.

Perdue, S. V., Reardon, R. C., \& Peterson, G. W. (2007). Person-environment congruence, self-efficacy, and environmental identity in relation to job satisfaction: A career decision theory perspective. Journal of Employment Counseling, 44(1), 29-39.

Pezirkianidis, C., Stalikas, A., Efstathiou, E., \&Karakasidou, E. (2016). The Relationship Between Meaning in Life, Emotions and Psychological Illness: The Moderating Role of the Effects of the Economic Crisis. The European Journal of Counselling Psychology, 4(1), 77-100, http://doi.org/10.5964/ejcop.v4i1.75

Reardon, R. C., Bullock, E. E., \& Meyer, K. E. (2007). A Holland perspective on the US workforce from 1960 to 2000. The Career Development Quarterly, 55(3), 262-274.

Tapson, C. (2016). Counselling and Professionalism: A Phenomenological Analysis of counselor Experience. The European Journal of Counselling Psychology, 4(2), 148165, http://doi.org/10.5964/ejcop.v4i2.51

Sevinc, K., Tasci, S., \& Demir, E. (2012). Some problems of psychological counseling and guidance system in Turkey. Procedia-Social and Behavioral Sciences, 46, 10561063. http://doi.org/10.1016/j.sbspro.2012.05.248

Watts, L. L., Frame, M. C., Moffett, R. G., Van Hein, J. L., \& Hein, M. (2015). The relationship between gender, perceived career barriers, and occupational aspirations. Journal of Applied Social Psychology, 45(1), 10-22. http://doi.org/10.1111/jasp.12271

Yilmaz, O. (2017). An evidence for validity of Holland's theory of personality types in Turkish culture. Psychology, 7(5), 264-273. http://doi.org/10.17265/2159/2017.05.002

Yuksel-Sahina, F. (2012). School counselors' assessment of the psychological counseling and guidance services they offer at their schools. Procedia-Social and Behavioral Sciences, 47, 327-339. 
Zikic, J. \& Hall, D.T. (2009). Toward a more complex view of career exploration. The Career Development Quarterly, 58(2), 181-191. 